\title{
Reduction of Food Commodities Contributor Inflation on Household Welfare Changes in The Province of Aceh
}

\author{
Yasrizal $^{1^{*}}$, Ishak Hasan ${ }^{2}$, and Yusnaidi ${ }^{3}$ \\ 1,3 Teuku Umar University, Meulaboh, Indonesia \\ ${ }^{2}$ Syiah Kuala University, Banda Aceh, Indonesia
}

\begin{abstract}
The relationship of inflation and poverty can be seen from the contribution of the commodity contributor poverty. Increases in the prices of commodities contributor to poverty led to declining real incomes and loss of income(incomeloss)households, causing poverty. Commodities contributor to poverty is dominated by food commodities. Rice and filter cigarettes are commodities contributor to poverty in Aceh most dominant. Model AIDS is a development of the Engel curve and Marshall equations derived from the theory of maximization of satisfaction. These models use a proportion of household expenditure on a commodity selected to represent variable demand. This research is empirical study. The data used are primary and secondary data obtained from field research and literature. Research will be located in Banda Aceh and Aceh Barat. Using the model of demand is almost ideal or model of AIDS will be seen household behavior in response to changes in commodity prices contributor of poverty. From these observations, the inflation rate of food commodities greatly affect the welfare of the people of Aceh province, both for household Banda Aceh and Meulaboh. Inflation of food commodities had a huge influence to reduce household welfare in Banda Aceh. Furthermore, the majority of households Meulaboh work in agriculture and fisheries. So it can meet its own needs and also be produksen. Many factors substitutes (goods substitution) and cultural factors affecting the level of price elasticity of the goods themselves for food commodities, changes in the elasticity of greater food in Banda Aceh than the district of Meulaboh.
\end{abstract}

Keywords: Elasticity, Food Commodities contributor to poverty, Inflation, Model of AIDS

\section{INTRODUCTION}

In the context regional economy, poverty is a problem often encountered in the process of economic development of a region. Characteristics and differences in economic resources of a region causing poverty rates also vary between regions. An area that has abundant natural resources, the human resources that support can attain a high level of economic growth and result in low levels of poverty. In contrast areas that have limited economic resources is identical with the relatively slow economic growth and high poverty rates.

\footnotetext{
* Corresponding author. Email address: yasrizal@utu.ac.id 44
} 
The poverty level of a country or region can be measured by per capita income of its people. Household spending may be an appropriate approach to see the magnitude of per capita income of the people. Based on this concept, the poor are people who have an average monthly per capita expenditure below the poverty line. The poverty rate will increase, especially when there is inflation, the rising prices of goods / services resulting in lower real income of society (BPS 2014).

Judging from the comparison between regions, Aceh is one of the provinces that have a low level of welfare, it can be seen from the poverty rate is high enough. Poverty in Aceh prevalent in rural areas, seen from the percentage of poverty in rural than in urban areas. In Table 1 shows that poverty levels are well above the national average.

Table 1

Poverty Aceh Province and the National Year 2011-2016 (In Percent)

\begin{tabular}{lcccc}
\hline \multicolumn{1}{c}{ Year } & \multicolumn{3}{c}{ Aceh Proverty Lever } & National Proverty Lever \\
\cline { 2 - 5 } & Urban & Rural & Total & Total \\
\hline 2012 & 14,65 & 23,54 & $\mathbf{2 0 , 9 8}$ & $\mathbf{1 3 , 3 3}$ \\
2013 & 13,69 & 21,87 & $\mathbf{1 9 , 5 7}$ & $\mathbf{1 2 , 3 6}$ \\
March 2014 & 13,07 & 21,97 & $\mathbf{1 9 , 4 6}$ & $\mathbf{1 1 , 9 6}$ \\
September 2014 & 12,47 & 20,97 & $\mathbf{1 8 , 5 8}$ & $\mathbf{1 1 , 6 6}$ \\
March 2015 & 11,59 & 19,96 & $\mathbf{1 7 , 6 0}$ & $\mathbf{1 1 , 3 7}$ \\
September 2015 & 11,55 & 20,1 & $\mathbf{1 7 , 7 2}$ & $\mathbf{1 1 , 4 7}$ \\
Mamarch 2016 & - & - & $\mathbf{1 8 . 0 5}$ & - \\
\hline
\end{tabular}

Source: BPS 2017

Poverty situation has an impact on the economy of Aceh, given Aceh still has a dependency on other regions in compliance with food. In September 2015 and March 2016 an increase in poverty, it is in line with the policy of withdrawal of fuel subsidies and fuel price hike by the government household. Calledpolicy administered price is leading to increased inflation in various commodities and lead to increased poverty, especially in rural households.

There is a close relationship between inflation and poverty. According to Wood etal.(2012), inflation in food would reduce economic welfare of lowincome households in both urban and rural areas, where the percentage of household expenditure on food will increase. The price increase will cause a loss of income (income loss) in the household. In line with this, Skoufias etal.(2011) found an increase in prices will have a direct impact on the increase in poverty.

The relationship of inflation and poverty can be seen from the contribution of the commodity contributor poverty. Commodities contributor to poverty is a household commodity staples consumptive. Increases in the prices of commodities contributor to poverty led to declining real incomes and loss of income(incomeloss)households, causing poverty. Commodities contributor to poverty is dominated by food commodities. Based on data from the Central Statistics Bandan Aceh province in 2017 contained in Table 2. 
Table 2

Commodity contributor to poverty timeframe of 2015 to 2016

in Aceh Province

\begin{tabular}{|c|c|c|c|c|c|c|}
\hline \multirow[t]{2}{*}{ Group } & \multirow{2}{*}{\multicolumn{2}{|c|}{ Comodity }} & \multicolumn{3}{|c|}{ Year 2015} & \multirow[t]{2}{*}{ Year } \\
\hline & & & Urba & Rural & Total & \\
\hline \multirow[t]{4}{*}{ Food } & Rice & & 32,16 & 40,74 & 35,81 & 39,92 \\
\hline & $\begin{array}{l}\text { Cigarettes } \\
\text { Filter }\end{array}$ & Kretek & 12,99 & 11,39 & 9,81 & 12,52 \\
\hline & Tuna/tong & & 7,49 & 5,85 & 7,18 & 5,95 \\
\hline & Sugar & & 4,63 & 5,19 & 5,06 & 4,86 \\
\hline
\end{tabular}

Source : BPS 2013

Rice is a commodity contributor to poverty in Aceh most dominant. Rice is the cause of poverty in urban areas amounted to $32.16 \%$, whereas in rural areas accounted for $40.74 \%$ rice in poverty. Other commodities accounted for poverty is the dominant filter cigarettes, where cigarettes cause poverty by $12.99 \%$ in urban areas and amounted to $11.39 \%$ in rural areas.

Policies in tackling the problem greatly influenced by the expectations and behavior of households. Households are assumed to always think rationally. When the government is planning to create a new policy, the policy has been anticipated household long before the policy is carried out. As a result of that policy bias as a form of time inconsistency. Micro approach is to study the behavior of households deeper so it can be the root of economic problems that exist.

The model uses micro-economic approach in an effort to see the economic welfare of households which are developed by Deaton and Muellbauer (1980), known as the model of AIDS (Almost Ideal Demand System). These models use a proportion of household expenditure on a commodity selected to represent variable demand. The advantages of this model is able to see the behavior of households in response to changes in prices and other goods at the same price, so that it can be seen the effect of price elasticity and shape of the goods themselves and the price of other goods. The elasticity can be an indicator of changes in household welfare. This model is consistent with the theory of demand as there are restrictions that can be incorporated into the model and can be used to test (Pusposari, 2012).

Based on the above, further researchers wanted to see how the level of economic welfare of households in terms of household demand for commodities contributor to poverty. Using the model of demand is almost ideal or model of AIDS will be seen household behavior in response to changes in commodity prices contributor of poverty. As a control variable, in this study will be also the elasticity of socio-demographic variables, including the number of family members and the level of education.

This study aims to look at changes in household welfare in the province of Aceh as seen from the coefficients of each variable, namely food commodities contributor to poverty, price elasticity and income elasticity, and elasticity of sociodemographic variables. Changes in the value of the elasticity coefficients and can looks at how changes in household welfare level due to rising commodity prices 
contributor to poverty and changes in other variables included in the model system of commodity demand contributor to poverty.

\section{LITERATURE REVIEW \\ Demand Theory and Model Almost Ideal Demand System (AIDS)}

Theory to explain the nature of the demand for a commodity buyer demand (goods and services) and also describes the relationship between the amount requested and the price as well as the formation of the demand curve. The proportion of expenditure as a proxy of demand developed by Deaton and Muelbauer (1980), known as Model Almost Ideal Demand System (AIDS). This model develops a demand function to include revenue and prices together. Demand for commodities is the expenditure share of commodities that are examined in the model of the total expenditure of all commodities in the system. According Pusposari (2012), The advantages of this model is the inclusion of other variables that could represent actual household conditions, such as sociodemographic variables, among others; education level, household size, income class, and others.

\section{Demand Price Elasticity and Welfare size}

Relationship between inflation, income and well-being can be seen from the opinions Skoufias et.al.(2011), namely; inflation would have a direct impact on the increase in poverty. In the short term, rising prices would be a serious problem in which the poor will be more spending money to buy food. The increase in prices will reduce real incomes so that they get poorer. On the other hand, manufacturers do not have the time to increase their production in response to price changes. In the long term rise in prices will reduce the welfare of middleclass households.

Price elasticity of demand (price elastisity of demand) is an indicator that measures consumer welfare, that is how big the demand changed as prices change. Measurements price elasticity of demand by looking at the percentage change in the number of requests divided by the percentage change in price. The income elasticity is a measure of the magnitude of response to the demand of goods to changes in consumer income, which is calculated as the percentage change in the number of requests divided by the percentage change in revenue (Curley etal.,2005)

\section{Inflation and Commodities contributor to poverty}

Inflation is an increase in prices of goods in general and on -menerus in certain periods. Inflation can be generally classified into two types, namely demand-pull inflation (due to demand-pull inflation) and cost-push inflation (inflation due to cost-push). To calculate the amount of inflation usually base the calculation is the Consumer Price Index (CPI). There are two patterns for the calculation of inflation in Indonesia, first, the calculation of inflation group of seven types of expenditure, namely; foodstuffs, processed foods, beverages, and tobacco, housing, clothing, health, education and sports, and transportation and communication. Commodities contributor to poverty fall into seven groups of these expenses. In fact, there is a close relationship, in which the commodity contributor to poverty is also included in the commodities contributor to inflation. 


\section{THE RESEARCH METHODS}

\section{ModelAnalysis}

\section{ModelAlmost Ideal Demand System (AIDS)}

Commodities contributor to poverty in this study are commodities that are causing the highest poverty. These commodities consists of six commodities, among others, are: Rice, Cigarettes / Tobacco, Sugar and Other Commodities

\section{Home Supplies.}

By using the Stone price index then the equation becomes linear and easy to estimate. Common models are then modified by social demographic variables such as household size, and education level. The following models of AIDS were used in this study.

$$
\mathrm{w}_{\mathrm{i}}=\mathrm{a} \partial_{\mathrm{i} 0}+\sum_{\mathrm{j}} \mathrm{\gamma}_{\mathrm{ij}} \log \mathrm{P}_{\mathrm{j}}+\beta_{\mathrm{i}} \log (\mathrm{x} / \mathrm{p} *)+\partial_{\mathrm{i} 1} \log \text { Family }+\partial_{\mathrm{i} 2} \log \mathrm{Edu}+\mu_{\mathrm{i}}
$$

Where:

$\mathrm{W}_{\mathrm{i}}$

: share expenditure to total expenditure commodity $\mathrm{i}, \mathrm{j}$

$\mathrm{i}=\mathrm{j}$

$: 1,2 \ldots 6$ (6 commodity contributor to poverty)

$\log \mathrm{P}_{\mathrm{j}}$ : the price of commodity $\mathrm{j}$ (where $\mathrm{j}=1,2 . .7$ )

$\log \left(\mathrm{x} / \mathrm{p}^{*}\right)$

$\mu_{\mathrm{i}}$ $: \log$ total income in deflation with the index log stone Family member numbers family household $\mathrm{i}$ : error term.

\section{Model Two Step Heckman}

Problem selectivity bias occurs because there are sampled households do not consume one particular commodities studied, for example, there are households that do not take up smoking. Model to solve the problem ismodel of two-stepestimation of Heckman, ie adding independent variable IMR(InverseMillsRatio)on the main model. IMR value obtained byregression logistic to estimate the odds of households to consume each commodity (Pusposari, 2012).

The first phase, regressed withmodels, logistic then the results will be obtained estimation value of IMR.

$$
\mathrm{Z}_{\mathrm{i}}=\mathrm{a} \partial_{\mathrm{i} 0}+\sum_{\mathrm{j}} \gamma_{\mathrm{ij}} \log \mathrm{P}_{\mathrm{j}}+\beta_{\mathrm{i}} \log (\mathrm{x} / \mathrm{p} *)+\partial_{\mathrm{i} 1} \log \text { Family }+\partial_{\mathrm{i} 2} \text { Class }+\mu_{\mathrm{i}}
$$

Where:

$\mathrm{Z}_{\mathrm{i}} \quad$ : Opportunities consumption, $0=$ do not consume and $1=$ consume

\section{Calculation Elasticity For Welfare Viewed}

From the estimation of the AIDS demand model, will then be used to calculate the elasticity. This elasticity calculations using the proportion of spending(budgetshare)the average of the i-th commodity groups. The following calculation formula of elasticity based on the estimation model of AIDS (Seftarita etal.,2013): 
1. The price elasticity itself: $\mathrm{EII}=1 \frac{\left(\gamma_{\left.i i-\beta_{i}, w_{i}\right)}\right.}{w_{i}}$

2. Price Elasticity Cross: $\quad \mathrm{Eij}=\frac{\left(\gamma_{\left.i j-\beta_{i}, w_{j}\right)}\right.}{w_{i}}$

3. income elasticity: Eiy $=\frac{\beta_{i}}{w_{i}}+1$

4. Elasticity social Demographics: $\quad \operatorname{Eik}=\frac{\partial_{i}}{w_{i}}$

\section{RESULTS AND DISCUSSION}

Table 3 shows household expenditure on basic commodities of food and non-food. Pengheluaran basic commodities is highest in households Meulaboh. The amount of spending on rice would reduce spending on other basic commodities. This condition is very different when compared with households Banda Aceh, where the expenditure is spread evenly between expenditure of food and non-food expenditures. Spending on education and health is low, not only in Meulaboh but also in household Banda Aceh. This indicates that the level of welfare is still low in the province.

Table 3 Commodity contributor to inflation in Aceh (Banda Aceh, Meulaboh)

\begin{tabular}{ccc}
\hline $\begin{array}{c}\text { Group Commodity } \\
\text { expenditure part }\end{array}$ & Meulaboh & Banda Aceh \\
\hline Rice & 0,420 & 0,276 \\
Tuna & 0,062 & 0,072 \\
Cigarette & 0,149 & 0,137 \\
Electric & 0,190 & 0,201 \\
LPG & 0,064 & 0,109 \\
Education & 0,115 & 0,201 \\
Health Services & 0,016 & 0,021 \\
\hline
\end{tabular}

\section{Welfare shift}

Commonly seen on demand food commodities, the value of elasticity for households Banda Aceh higher relative to households Meulaboh. This suggests that food inflation has a major influence on the decline in household welfare for Banda Aceh. This condition is mainly caused by several factors, first: Aceh Village is an area of the highest producing agricultural and fishery commodities, so that households Meulaboh can meet their basic food needs at reasonable prices or even that they can produce their own food needs. Second: there are a lot of commodity substitution in the market, especially for commodities tuna. The third: for the cigarette commodities, consumers in households Meulaboh higher than households Banda Aceh. Culture coffee shop and smoke in smoking households Meulaboh Meulaboh own-elasticty lead to a lower price than cigarettes own-price elasticity of domestic Banda Aceh. This indicates that the price of cigarettes does not have a big impact on demand for cigarettes in the Meulaboh area. 
Table 4 Elasticity Komditas Food (by Marshallian)

\begin{tabular}{ccc}
\hline Comodity & Region & elastisity \\
\hline Rice & Meulaboh & -0.125 \\
& Banda Aceh & -0.608 \\
\hline Tuna & Meulaboh & $-0,945^{*}$ \\
& Banda Aceh & $-0.999 *$ \\
\hline Filter Kretek Cigarettes & Meulaboh & $-0,974$ \\
& Banda Aceh & -0.710 \\
\hline
\end{tabular}

\section{*) Significance on the validity of the 95 per cent}

Table 4 indicates a shift in the price elasticity of the goods themselves that reflects changes in the level of household welfare in Aceh due to price changes in food inflation. High inflation in the Month in March 2017 led to a decrease in welfare households Meulaboh and Banda Aceh. This condition is seen from the increased value of goods own price elasticity for each food commodity prices. Demand tuna and cigarettes increased to elastic. Generally, this condition indicates that there is an increase in household wealth due to a drop in inflation. In July inflation rises again and the highest inflation rate during the study period. July inflation due to the increase in the value of the price elasticity of the goods themselves resulted terhapad lowering household wealth in the province of Aceh

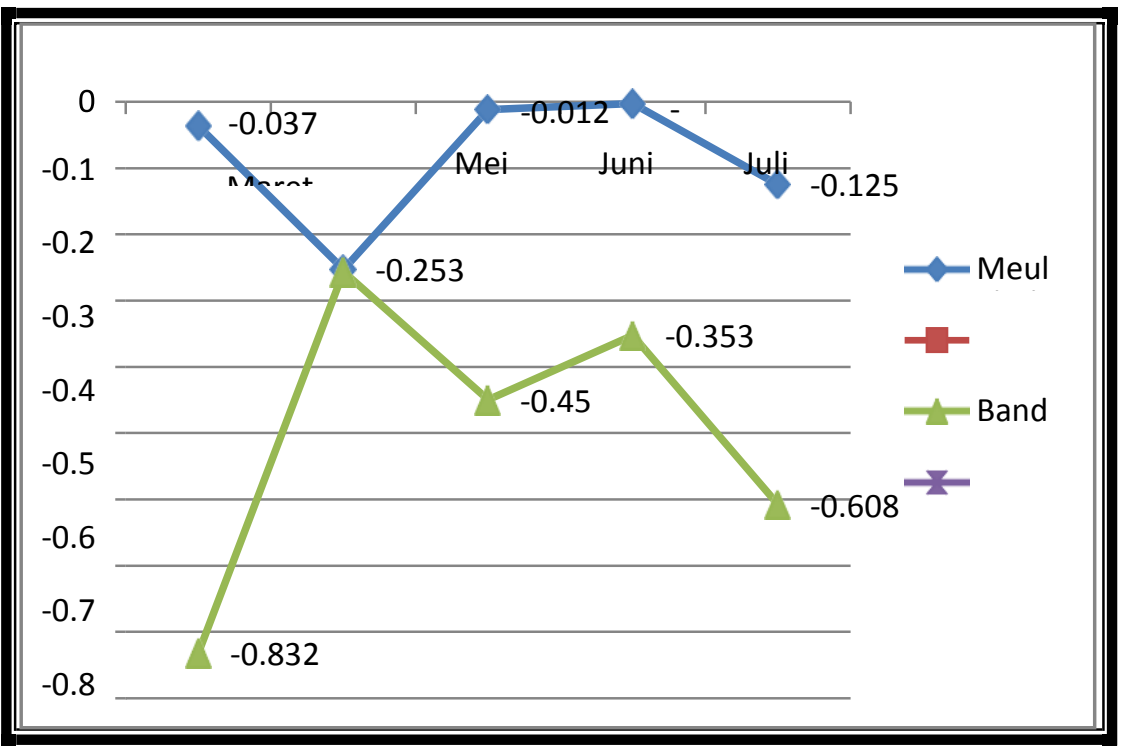

Figure 1 Change Requests Rice Price elasticity between March and July 2017 


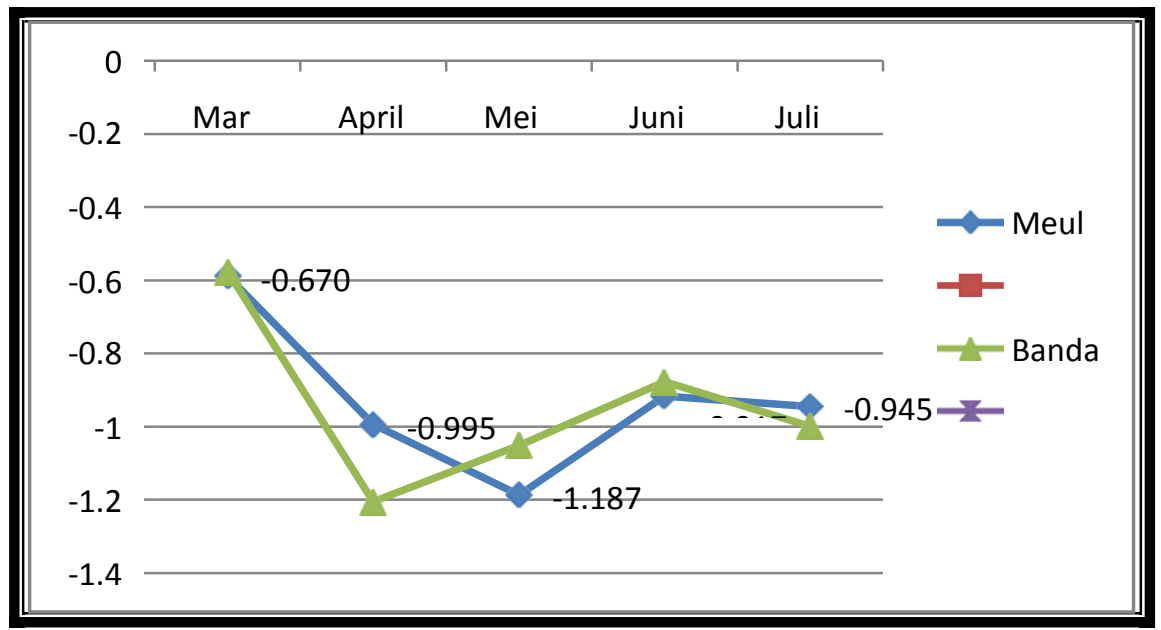

Figure 2 Changes in Demand Price elasticity Tuna: between March and July 2017

Figures 1 and 2 show a shift from rice price elasticity. The elasticity value in Banda Aceh households is higher relative to households Meulaboh. The elasticity is not shown to be significantly in statistical testing both in households Meulaboh and Banda Aceh. This condition is caused by changes in household income is lower than the Meulaboh Banda Aceh households, households Meulaboh more responsive to the increase in food commodity prices. Figure 3 shows the elasticity of tuna. Inflation in March to May has led to a decrease in household welfare in the area of Banda Aceh, and it is higher than households Meulaboh. This is demonstrated by the increase in own-price elasticity becomes elastic. But in May of household wealth in Banda Aceh were changed and it was higher than in households Meulaboh. This is indicated by changes in the price elasticity of the goods themselves. In June the value of goods own price elasticity decreased both in the area of Meulaboh and Banda Aceh. Lowest inflation emerged during the study period and it makes household welfare for the better. In July 2017, an increase in inflation of food commodities led to a decrease in household welfare Banda Aceh and Meulaboh. The elasticity in Banda Aceh households is higher than households Meulaboh 


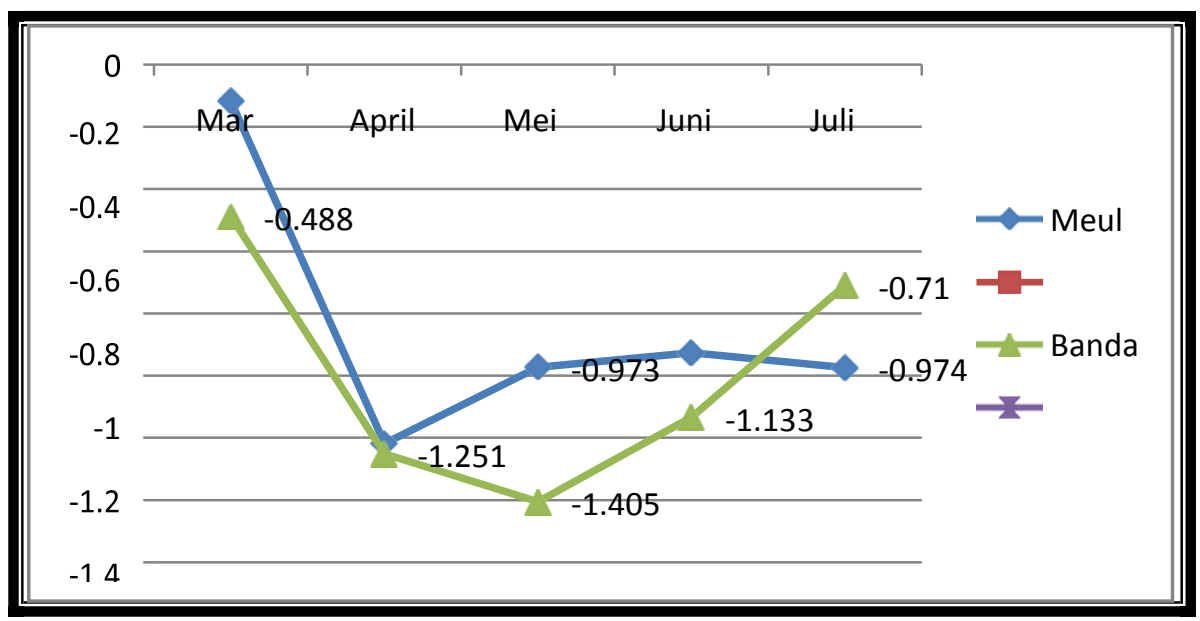

Figure 3 Change Requests Price elasticity smoking between March and July 2017

For non commodity, a price elasticity alone in the household goods Banda Aceh is higher than households Meulaboh. This indicates that the rise in price of cigarettes each year smoking causes a decrease in consumer welfare in households Banda Aceh and lower than households Meulaboh. In addition, cigarette consumers in households Meulaboh higher than households Banda Aceh. Coffeehouse culture and a smoke in the Meulaboh area also affected the value of the price elasticity of the goods themselves to cigarette commodities in households Meulaboh. As we know, Aceh is very popular with the culture of the coffee shop, which affect people's behavior more dominant coffee consumption

\section{CONCLUSIONS AND SUGGESTIONS Conclusions}

From these observations, the inflation rate of food commodities greatly affect the welfare of the people of Aceh province, both for household Banda Aceh and Meulaboh. Inflation of food commodities had a huge influence to reduce household welfare in Banda Aceh. Furthermore, the majority of households Meulaboh work in agriculture and fisheries. So it can meet its own needs and also be produksen. Many factors substitutes (goods substitution) and cultural factors affecting the level of price elasticity of the goods themselves for food commodities, food elasticity greater change occurred in the Banda Aceh Meulaboh compared with the district. In contrast, non-inflationary effect of food commodities more in the households Meulaboh. Differences in household income levels lead to Meulaboh be very sensitive to a rise in inflation.

\section{Suggestions}

- There are a few key points bedasarkan findings of this study. First Bank Indonesia (BI) as a monetary authorization must control inflation, then the Aceh government should take part in controlling inflation in Aceh by enhancing the supply side through increased spending policies in the region to 
engage in crop farming sector investment and non-food konoditi. Increased production pangandapat controlling food inflation. Aceh government should encourage the growth of agriculture and fisheries sectors to maintain the availability of production. The government should regulate the smooth distribution of each commodity for the vital needs of society, including LPG. Because of the different prices between regions due to poor distribution.

\section{References}

Bosch, A., \& Koch, S. F. (2009). Inflation and the Household: Towards a Measurement of the Welfare Costs of Inflation. South African Reserve Bank Working Paper, 2, 1-52.

Curley, S., Sudjana, R., Herlambang, R. B., \& Sugiarto. (2005). Microeconomics A Comprehensive Assessment. Jakarta: PT Gramedia Pustaka Utama.

Kahar, M. (2010). Analysis of Consumption of Urban and Rural And Correlation With Socioeconomic Characteristics in Banten. [Thesis]. Bogor: Bogor Agricultural University, 1-72.

Martin, W., Ivanic, M., \& Zaman, H. (2012). Estimating the Short-Run Poverty Impacts of the 2010-11 Surge in Food Prices. World Development, 40(11), 2302-2317.

Muellbauer, J., \& Deaton, A. (2008). An Almost Ideal Demand System. Journal of STOR,70, 312-326.

Skoufias, E. (2003). Is the Calorie-Income Elasticity Sensitive to Price Changes?

Evidence from Indonesia. World Development, 31(7), 1291-1307.

Pons, N. (2011). Food and Prices in India: Impact of Rising Food Prices on Welfare, Center de Sciences humaines,1-33.

Pusposari, F. (2012). Analysis of Food Consumption Pattern Communities in Maluku Province. [Thesis]. Depok: University of Indonesia, 1-86.

Seftarita, C., Shakir, A., Nasir, M., \& Masbar, R. (2013). Analysis of Public Consumption Behavior Of Commodities contributor to inflation. Bank Indonesia and Economics faculty Unsyiah, 1-58.

Seftarita, C. (2014). Macroeconomic Policy and Business Cycles: Theory and Empirical Study. Banda Aceh: Syiah Kuala University Press.

Susenas. 2008-2012. Consumption Expenditure For The Indonesian population per province. Book 3, the Central Bureau of Statistics.

Skou fi as, E., Tiwari, S., \& Zaman, H. (2011). Crises, Food Prices and The Income Elasticity Of Micronutrients: Estimates From Indonesia. World Bank Economic Review. 
Tash, M. N. S., Shahraki, J., \& Jangi, S. N. (2012). Estimating the Almost Ideal Demand System Models For Rural Households in Iran. International Journal of Academic Research in Business and Social Sciences, 2(8), 344355.

www.bps.go.id. 2017. 